\title{
MODEL PENENTUAN OPERASI PASAR UNTUK MENDUKUNG STABILISASI HARGA MINYAK GORENG CURAH:STUDI KASUS
}

\author{
Anis Maisyaroh, Ayu Pratiwi, Muh. Hisjam, Wahyudi Sutopo \\ Program Studi Teknik Industri \\ Universitas Sebelas Maret Surakarta 57126 \\ anismaisyaroh30@gmail.com; ayupratiwi50@gmail.com; \\ hisjam@gmail.com; wahyudisutopo@gmail.com
}

\begin{abstract}
Abstrak
Operasi pasar murah minyak goreng curah dimaksudkan untuk menstabilkan harga dan membantu menjaga ketersediaannya di masyarakat. Akan tetapi, terkadang penentuan jumlah minyak goreng curah yang dijual di operasi pasar juga belum direncanakan sehingga operasi pasar tidak sesuai sasaran. Tujuan dari artikel ini adalah menentukan lokasi operasi pasar yang strategis atau merupakan titik terdekat dari lima kecamatan dan kuantitas minyak goreng yang dibutuhkan untuk tercapainya operasi pasar dengan harga yang diinginkan dan mencapai stabilisasi harga. Metode yang digunakan untuk menentukan lokasi operasi pasar adalah metode pusat gravitasi satu titik dan dua titik. Sedangkan untuk penentuan kuantitas minyak goreng yang dibutuhkan untuk operasi pasar ditentukan berdasarkan hukum keseimbangan pasar. Dengan pengkombinasian metode pusat gravitasi dan teori keseimbangan pasar dapat ditentukan lokasi dan kuantitas yang tepat untuk operasi pasar minyak goreng curah di Kota Surakarta. Implikasi manajerial dari model yang telah disusun dapat digunakan sebagai bahan pertimbangan bagi Dinas Perindustrian dan Perdagangan serta Tim Pengendali Inflasi Daerah (TPID) dalam menentukan lokasi dan kuantitas minyak goreng yang dibutuhkan untuk operasi pasar.
\end{abstract}

Kata kunci : Hukum Keseimbangan Pasar, Metode Pusat Gravitasi, Minyak Goreng Curah, Operasi Pasar, Stabilisasi Harga

\section{PENDAHULUAN}

Minyak goreng merupakan salah satu dari sembilan bahan pokok yang dikonsumsi oleh seluruh lapisan masyarakat (Yulia, 2011). Minyak goreng adalah salah satu kebutuhan pokok masyarakat Indonesia dalam rangka pemenuhan kebutuhan sehari-hari. Salah satu jenis minyak goreng adalah minyak goreng curah. Minyak goreng curah merupakan minyak goreng hasil olahan pengusaha industri kecil yang memerlukan penanganan yang lebih mengingat proses pengolahannya yang bersifat tradisional (Rahayu, dkk, 2007). Masyarakat Indonesia lebih banyak menggunakan minyak goreng curah dibandingkan minyak yang bermerk karena harganya lebih murah (Yulia, 2011). Harga minyak goreng curah mengalami peningkatan dan terjadi disparitas harga. Pada bulan Desember 2013, harga minyak goreng curah dalam negeri mengalami peningkatan sebesar 1,62\% jika dibandingkan dengan bulan sebelumnya. Disparitas harga minyak goreng curah antar wilayah pada bulan Desember 2013 masih relatif tinggi namun mengalami penurunan dibandingkan bulan sebelumnya. Koefisien keragaman antar wilayah bulan Desember 2013sebesar 12,51\% (Wahyuniarti, 2013). Peningkatan harga dan disparitas harga minyak gorengcurah juga terjadi di Kota Surakarta.

Kota Surakarta merupakan kota yang terdiri dari lima kecamatan, yaitu Kecamatan Banjarsari, Jebres, Laweyan, Pasar Kliwon, dan Kecamatan Serengan. Jumlah penduduk Kota Surakarta adalah sebanyak 552.650 jiwa, sehingga mereka memiliki kebutuhan minyak goreng curah yang cukup tinggi (Dispendukcapil, 2015). Kebutuhan minyak goreng curah di 
Kota Surakarta sudah terpenuhi, bahkan menurut Sugeng Prayitno selaku Kepala Seksi Kewaspadaan Pangan Kota Surakarta, pasokan minyak goreng curah di Kota Surakarta didapatkan dari Semarang dan Surabaya. Menurutnya, Kota Surakarta tidak pernah mengalami kekurangan ketersediaan minyak goreng curah selama sepuluh tahun terakhir. Namun, permasalahannya adalah terjadinya disparitas harga antara Pasar Legi (pasar induk) dengan Pasar Gede (pasar kelas atas), Pasar Jongke (pasar kelas menengah), dan pasar tradisional lainnya. Hal ini dapat terjadi karena Pasar Legi merupakan tempat pendistribusian pertama untuk pasokan minyak goreng di Surakarta, pasokan tersebut kemudian akan didistribusikan ke pasar-pasar komoditas lainnya. Selain itu, disparitas harga tersebut juga dipengaruhi oleh jumlah permintaan (demand) dan jumlah penawaran (supply). Disparitas akan semakin besar ketika harga minyak goreng naik secara drastis ketika menjelang hari besar keagamaan.

Permasalahan distribusi yang menyebabkan terjadinya disparitas harga minyak goreng tersebut dapat diselesaikan dengan stabilisasi harga. Stabilisasi harga adalah tindakan yang dilakukan untuk mencegah terjadinya lonjakan harga yang dapat meresahkan masyarakat setelah melakukan upaya pemantauan dan evaluasi perkembangan harga (Kemendag, 2012). Stabilisasi harga dapat dilakukan untuk jangka panjang dan jangka pendek. Salah satu contoh stabilisasi harga untuk jangka panjang adalah dengan menambahkan papan harga yang disertai dengan jumlah stok yang ada pada pasar tradisional, sehingga konsumen mengetahui harga minyak goreng curah pada saat itu. Sedangkan salah satu cara stabilisasi harga untuk jangka pendek adalah dengan melakukan operasi pasar. Operasi pasar adalah tindakan pemerintah dalam rangka menangani lonjakan harga yang terjadi di daerah tertentu selama jangka waktu tertentu (Kemendag, 2012).

Pada studi kasus di Kota Surakarta, operasi pasar pernah dilakukan antara lain pada tahun 2015 di Pasar Gede, Lapangan Penumping Laweyan, dan Keraton Kasunanan Surakarta (Pranoto, 2015). Operasi pasar dilakukan oleh Dinas Perdagangan dan Perindustrian Kota Surakarta atau Bulog dan Tim Pengendali Inflasi Daerah (TPID) Kota Surakarta. Biasanya operasi pasar dilakukan menjelang hari besar keagamaan seperti lebaran atau ketika bulan Ramadhan tiba, serta menjelang Natal dan Tahun Baru. Pada tahun 2016 ini, menurut Kepala Bidang Perdagangan Kota Surakarta, Sri Redjeki rencananya operasi pasar komoditas murah akan digelar pada bulan Ramadhan ini dan akan dimulai pada 1 Juli serentak di lima Kecamatan yaitu Kelurahan Banjarsari yang bertempat di Kelurahan Sumber, Laweyan di kelurahan Penularan, Serengan di Kelurahan Tipes, Jebres di Kelurahan Sudiroprajan, dan Pasar Kliwon di Kelurahan Kedung Lumbu (Hazliansyah, 2016). Operasi pasar yang dilakukan tersebut sudah cukup baik karena menurunkan harga minyak goreng Surakarta yang melambung tinggi ketika menjelang hari besar. Kekurangan dari operasi pasar tersebut adalah lokasinya yang tidak strategis atau bukan merupakan titik terdekat dari lima kecamatan sehingga aspek keadilannya tidak merata. Selain itu, ketika operasi pasar dilakukan di pasar tradisional muncul kesalahan sasaran, yaitu minyak goreng justru dibeli oleh para penjual di pasar bukan para konsumen.

Pada penelitian ini, ditentukan lokasi operasi pasar yang strategis atau merupakan titik terdekat dari lima kecamatan dan kuantitas minyak goreng yang dibutuhkan untuk operasi pasar agar harga yang diinginkan tercapai. Ada beberapa metode yang dapat digunakan untuk menentukan lokasi, salah satunya metode pusat gravitasi. Metode pusat gravitasi banyak dipakai untuk menentukan lokasi persediaan (gudang) tetap pada masalah untuk meminimalkan beberapa biaya produksi dan transportasi (Wilson, 2003). Selain itu, metode 
pusat gravitasi juga dapat digunakan untuk menentukan lokasi pusat logistik untuk menyelesaikan masalah distribusi logistik sehingga dapat mengurangi biaya operasi logistik (Ying, Zhae X., 2014). Penelitian lain menyebutkan metode pusat gravitasi digunakan untuk menentukan lokasi untuk pusat distribusi buah-buahan dan sayuran lokal (Selimi, 2013). Penelitian yang dilakukan Onnela (2015) telah menggunakan teori pusat gravitasi dengan mempertimbangkan faktor kuantitatif yaitu faktor politik, sosial, kultural, dan logistical serta faktor kuantitatif yang berupa kuantitas distribusi. Namun, penelitian sebelumnya belum ada yang mengadopsi metode pusat gravitasi untuk penentuan lokasi operasi pasar. Sehingga pada penelitian ini, untuk menentukan lokasi operasi pasar digunakan metode pusat gravitasi. Metode pusat gravitasi dapat digunakan karena dapat menentukan lokasi yang paling strategis atau merupakan titik terdekat untuk konsumen pada masing-masing kecamatan yang dipengaruhi oleh jarak masing-masing lokasi pasar tradisional dan tingkat kebutuhan minyak goreng curah per kecamatan. Sehingga dengan metode gravitasi, konsumen pada tiap kecamatan dapat menjangkau letak operasi pasar dengan mudah. Sedangkan untuk penentuan jumlah atau kuantitas minyak goreng yang dibutuhkan untuk operasi pasar ditentukan berdasarkan hukum keseimbangan pasar. Hukum keseimbangan pasar menyatakan bahwa peningkatan penawaran akan menyebabkan menurunnya keseimbangan harga dan meningkatkan kuantitas penawaran.

\section{LANDASAN TEORI}

\section{A. Kajian Pustaka}

Sudah banyak penelitian yang menggunakan metode pusat gravitasi untuk menentukan lokasi gudang untuk men-suplai berbagai toko dengan jarak dan kapasitas yang berbeda-beda.Penelitian yang telah dilakukan oleh Nurendah dan Mulyana (2012) telah menggunakan pendekatan metode pusat gravitasi untuk menentukan lokasi pusat gudang Toko Giant Botani Square Bogor. Penentuan lokasi dengan metode ini mempertimbangkan bahwa jarak merupakan faktor penting yang dapat mempengaruhi biaya transportasi dari beberapa toko yang tersebar di kota Bogor.

Saraswati (2015) juga meneliti mengenai penentuan lokasi gudang pada bisnis retail menggunakan metode pusat gravitasi. Lokasi gudang ditentukan dari 12 toko yang tersebar di berbagai lokasi dengan kapasitas setiap toko yang berbeda-beda. Selimi (2013) dalam penelitiannya metode pusat gravitasi digunakan untuk menentukan lokasi pusat distribusi buah dan sayuran. Penentuan pusat logistik dalam menangani masalah strategis adalah penting sehingga dapat meminimalisasi biaya logistik (Ying, 2014). Penentuan pusat distribusi Eropa Kalmar telah dilakukan dengan mempertimbangkan faktor-faktor kuantitatif berupa faktor sosial, politik, kultural dan logistical sertamempertimbangkanfakorkualitatif (Onnela, 2015).

\section{B. Metode Pusat Gravitasi}

Menurut Heizer\& Render (2013) dalam menemukan lokasi terbaik untuk menjadi pusat distribusi diperhitungkan lokasi pasar, volume barang yang dikirim ke pasar, dan biaya pengangkutan.Data yang dibutuhkan untuk mengolah data dengan metode pusat gravitasi antara lain titik koordinat dari setiap lokasi kebutuhan atau volume barang di terminal. Penentuan lokasi dengan menggunakan pusat gravitasi dapat ditentukan dengan menggunakan sebagai berikut.

$$
C_{x}=\frac{\sum_{i} d_{i x} w_{i}}{\sum_{i} w_{i}}
$$


$C_{y}=\frac{\sum_{i} d_{i y} w_{i}}{\sum_{i} w_{i}}$

Dimana $\mathrm{C}_{\mathrm{x}}$ merupakan hasil koordinat $\mathrm{x}$ dari perhitungan pusat gravitasi, $\mathrm{C}_{\mathrm{y}}$ merupakan koordinat y dari pusat gravitasi, $\mathrm{d}_{\mathrm{ix}}$ merupakan koordinat $\mathrm{x}$ dari setiap terminal, $\mathrm{d}_{\mathrm{iy}}$ merupakan koordinat y dari terminal dan $\mathrm{w}_{\mathrm{i}}$ merupakan kebutuhan atau volume barang dari setiap terminal.

\section{KeseimbanganPasar}

Hukum keseimbangan pasar menyatakan bahwa peningkatan penawaran akan menyebabkan menurunnya keseimbangan harga dan meningkatkan jumlah atau kuantitas. Jika So (supply o) bergeser ke kanan, pada keseimbangan baru P akan turun dan Q akan naik seperti yang ditunjukkan pada gambar 1 .

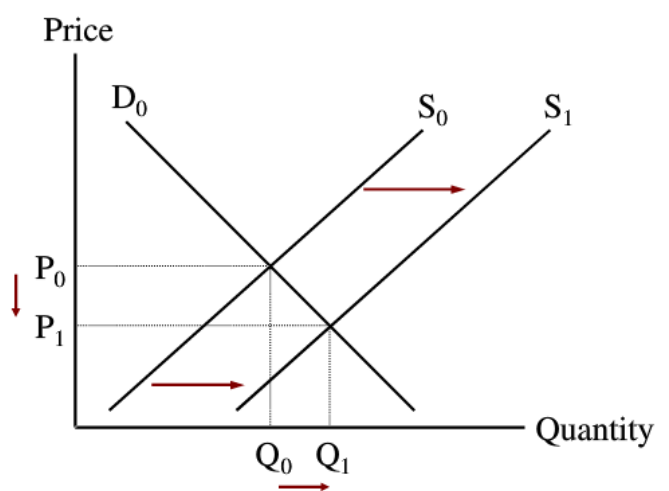

Gambar 1. Hukum Keseimbangan Pasar

Berdasarkan hukum tersebut, maka yang dapat dilakukan untuk menurunkan harga adalah dengan menambah penawaran. Berikut ini adalah penentuan persamaan penawaran minyak goreng di pasar per bulan.

$$
\frac{P-P 1}{P 2-P 1}=\frac{Q-Q 1}{Q 2-Q 1}
$$

MenurutNuryanti (2005), jika harga dari suatu komoditas mengalami kenaikan dengan faktor lain tidak berubah maka akan mendorong produsen untuk meningkatkan jumlah komoditas yang ditawarkan. Begitu juga sebaliknya, jika harga dari suatu komoditas akan menurun maka akan mendorong produsen untuk mengurangi jumlah komoditas yang ditawarkan.

\section{METODE PENELITIAN}

\section{Pengumpulan Data}

Pada artikel ini digunakan data primer dan data sekunder. Data primer yang digunakan adalah dengan melakukan wawancara dengan staff Perdagangan Dalam Negeri, Dinas Perindustrian Kota Surakarta dan kepala seksi Kewaspadaan Pangan, Dinas Ketahanan Pangan Kota Surakarta. Sedangkan data sekunder merupakan data yang diperoleh secara tidak langsung. Pada artikel ini data sekunder yang digunakan adalah lokasi pasar di Surakarta menggunakan Google Maps, daftar harga minyak goreng curah dari tiga pasar yaitu Pasar Legi, Pasar Gede, dan Pasar Jongke, daftar kebutuhan dan pasokan minyak goreng di Surakarta, serta jumlah penduduk kota Surakarta. 
2. Pengolahan Data

Data yang telah terkumpul kemudian diolah, daftar harga yang diperoleh merupakan daftar harga perhari kemudian diolah menjadi per minggu selama 25 minggu. Selain itu juga dilakukan pengolahan data untuk disparitas harga antara harga induk yaitu dari Pasar Legi dengan Pasar Gede dan Pasar Jongke.

3. Analisis

Metode pengolahan data untuk menentukan lokasi pasar satu titik dan dua titik adalah dengan menggunakan metode pusat gravitasi. Penentuan dua titik dilakukan dengan membagi kota Surakarta menjadi dua region yaitu region barat dan region timur. Pembagian ini berdasarkan hasil penentuan lokasi pasar dengan satu titik yaitu region barat adalah daerah pasar yang memiliki koordinat latitudelebih kecil daripada latitude pusat gravitasi satu titik.Kemudian region timur adalah daerah pasar yang memiliki koordinat latitude lebih besar daripada latitude pusat gravitasi satu titik. Setelah menemukan lokasi koordinat yang menjadi pusat maka dilakukan pengecekan lokasi tersebut dan disesuaikan apakah lokasi tersebut memungkinkan untuk dijadikan lokasi operasi pasar, jika tidak maka dicari lokasi lain yang berdekatan dan memungkinkan.Selain itu juga dilakukan analisis keseimbangan pasar untuk mengetahui kuantitas dari minyak goreng yang harus tersedia pada operasi pasar.

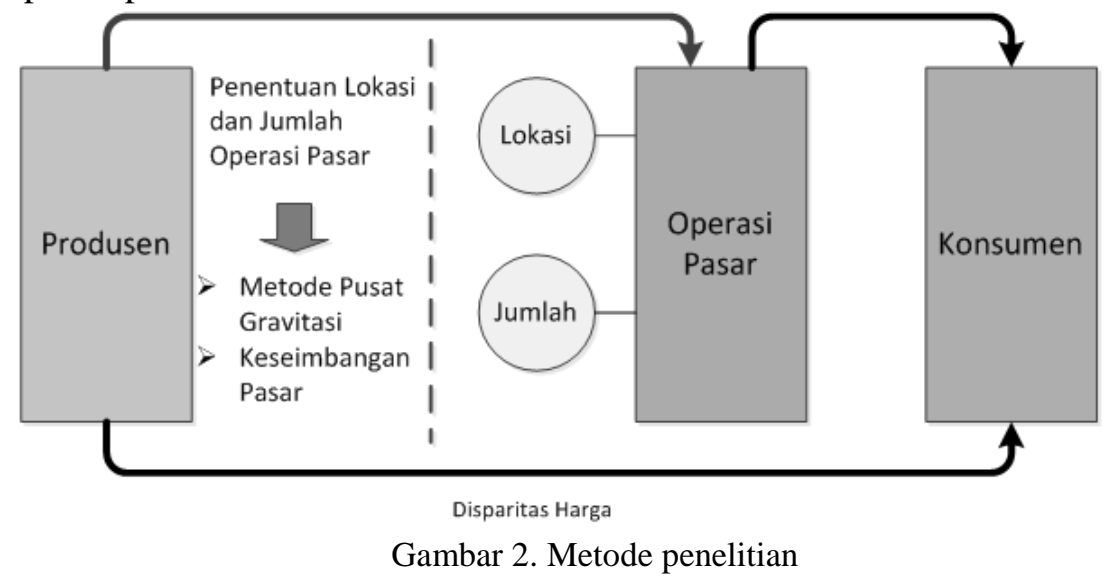

\section{HASIL DAN PEMBAHASAN}

\section{A. Fluktuasi Harga Minyak Goreng Curah}

Gambar 3 menunjukkan fluktuasi harga minyak goreng pada 30 November 2015 hingga 21 Mei 2016. Berdasarkan gambar tersebut menunjukkan bahwa dari ketiga pasar di kota Surakarta yaitu Pasar Legi Pasar, Gede, dan Pasar Jongke, Pasar Legi-lah yang memiliki harga paling rendah diantara kedua pasar lainnya. Hal ini dapat terjadi karena Pasar Legi merupakan tempat pendistribusian pertama untuk pasokan minyak goreng di Surakarta, pasokan tersebut kemudian akan didistribusikan ke pasar-pasar komoditas lainnya.

Pada Gambar3 juga menunjukkan bahwa harga minyak goreng curah cenderung mengalami trend kenaikan harga. Kenaikan harga paling drastis terjadi pada minggu ke 15 hingga minggu ke 17 yang jatuh pada tanggal 6 Maret 2016 hingga 26Maret 2016. Kenaikan tersebut terjadi untuk ketiga pasar utama di kotaSurakarta yaitu Pasar Legi, Pasar Gede, dan Pasar Jongke. Harga minyak goreng curah cenderung stabil pada minggu ke 23 dan minggu ke 25 (selama bulan Mei 2016). 
Tabel 1. Harga minyak goreng curah untuk Pasar Gede, Pasar Legi, dan Pasar Jongke

\begin{tabular}{|c|c|c|c|c|c|c|c|c|c|c|}
\hline $\begin{array}{c}\text { Minggu } \\
\text { Ke- }\end{array}$ & Tanggal & $\begin{array}{l}\text { Pasar } \\
\text { Gede }\end{array}$ & $\begin{array}{l}\text { Pasar } \\
\text { Legi }\end{array}$ & & & $\begin{array}{c}\text { Minggu } \\
\text { Ke- }\end{array}$ & Tanggal & $\begin{array}{l}\text { Pasar } \\
\text { Gede }\end{array}$ & $\begin{array}{l}\text { Pasar } \\
\text { Legi }\end{array}$ & $\begin{array}{c}\text { Pasar } \\
\text { Jongke }\end{array}$ \\
\hline 1 & $\begin{array}{l}30 \text { Nov' } 15 \text { s/d } \\
5 \text { Des '15 }\end{array}$ & Rp 10.000 & Rp 9.000 & $\mathrm{Rp}$ & 9.500 & 14 & $\begin{array}{l}28 \text { Feb '16 s/d } \\
5 \text { Mar '16 }\end{array}$ & Rp10.600 & Rp 9.800 & Rp 9.960 \\
\hline 2 & $\begin{array}{l}6 \text { Des ' } 15 \text { s/d } \\
12 \text { Des '15 }\end{array}$ & $\operatorname{Rp} 10.000$ & Rp 9.000 & $\mathrm{Rp}$ & 9.500 & 15 & $\begin{array}{l}6 \text { Mar '16 s/d } \\
12 \operatorname{Mar}^{\prime} 16\end{array}$ & Rp11.250 & Rp10.500 & Rp 10.750 \\
\hline 3 & $\begin{array}{l}13 \text { Des ' } 15 \text { s/d } \\
19 \text { Des '15 }\end{array}$ & Rp 10.000 & Rp 9.000 & $\mathrm{Rp}$ & 9.500 & 16 & $\begin{array}{l}13 \text { Mar '16 s/d } \\
19 \text { Mar '16 }\end{array}$ & Rp11.400 & Rp10.400 & Rp11.000 \\
\hline 4 & $\begin{array}{l}20 \text { Des ' } 15 \text { s/d } \\
26 \text { Des ' } 15\end{array}$ & Rp $\quad 9.833$ & Rp 8.750 & $\mathrm{Rp}$ & 9.333 & 17 & $\begin{array}{l}20 \text { Mar '16 s/d } \\
26 \text { Mar '16 }\end{array}$ & Rp11.333 & Rp10.000 & Rp11.000 \\
\hline 5 & $\begin{array}{l}27 \text { Des ' } 15 \text { s/d } \\
2 \text { Jan '16 }\end{array}$ & Rp 9.625 & Rp 8.750 & $\mathrm{Rp}$ & 9.188 & 18 & $\begin{array}{l}27 \text { Mar '16 s/d } \\
2 \text { Apr '16 }\end{array}$ & Rp11.700 & Rp10.100 & Rp 10.600 \\
\hline 6 & $\begin{array}{l}3 \text { Jan '16 s/d } 9 \\
\text { Jan '16 }\end{array}$ & Rp 10.000 & Rp 9.500 & $\mathrm{Rp}$ & 9.750 & 19 & $\begin{array}{l}3 \text { Apr ' } 16 \text { s/d } 9 \\
\text { Apr '16 }\end{array}$ & Rp12.000 & Rp11.000 & Rp11.500 \\
\hline 7 & $\begin{array}{l}10 \text { Jan '16 s/d } \\
16 \text { Jan '16 }\end{array}$ & $\operatorname{Rp} 10.000$ & Rp 9.500 & $\mathrm{Rp}$ & 9.750 & 20 & $\begin{array}{l}10 \text { Apr ' } 16 \text { s/d } \\
16 \text { Apr ' } 16\end{array}$ & Rp12.000 & Rp11.000 & Rp11.380 \\
\hline 8 & $\begin{array}{l}17 \text { Jan '16 s/d } \\
23 \text { Jan '16 }\end{array}$ & Rp 10.000 & Rp 9.000 & $\mathrm{Rp}$ & 9.500 & 21 & $\begin{array}{l}17 \text { Apr '16 s/d } \\
23 \text { Apr '16 }\end{array}$ & Rp12.100 & Rp11.100 & Rp11.480 \\
\hline 9 & $\begin{array}{l}24 \text { Jan '16 s/d } \\
30 \text { Jan '16 }\end{array}$ & Rp 10.000 & Rp 9.000 & $\mathrm{Rp}$ & 9.500 & 22 & $\begin{array}{l}24 \text { Apr ' } 16 \text { s/d } \\
30 \text { Apr '16 }\end{array}$ & Rp12.500 & Rp11.500 & Rp 12.000 \\
\hline 10 & $\begin{array}{l}31 \text { Jan '16 s/d } \\
6 \text { Feb '16 }\end{array}$ & $\operatorname{Rp} 10.000$ & Rp 9.000 & $\mathrm{Rp}$ & 9.500 & 23 & $\begin{array}{l}1 \mathrm{Mei} \text { '16 s/d } 7 \\
\text { Mei'16 }\end{array}$ & Rp12.500 & Rp11.500 & Rp12.333 \\
\hline 11 & $\begin{array}{l}7 \text { Feb '16 s/d } \\
13 \text { Feb '16 }\end{array}$ & Rp 10.000 & Rp 9.350 & $\mathrm{Rp}$ & 9.600 & 24 & $\begin{array}{l}8 \mathrm{Mei} \text { '16 s/d } \\
14 \text { Mei'16 }\end{array}$ & Rp12.500 & Rp11.500 & Rp 12.000 \\
\hline 12 & $\begin{array}{l}14 \text { Feb '16 s/d } \\
20 \text { Feb '16 }\end{array}$ & Rp 10.000 & Rp 9.500 & $\mathrm{Rp}$ & 9.600 & 25 & $\begin{array}{l}15 \text { Mei '16 s/d } \\
21 \text { Mei '16 }\end{array}$ & Rp12.500 & Rp11.500 & Rp12.063 \\
\hline
\end{tabular}

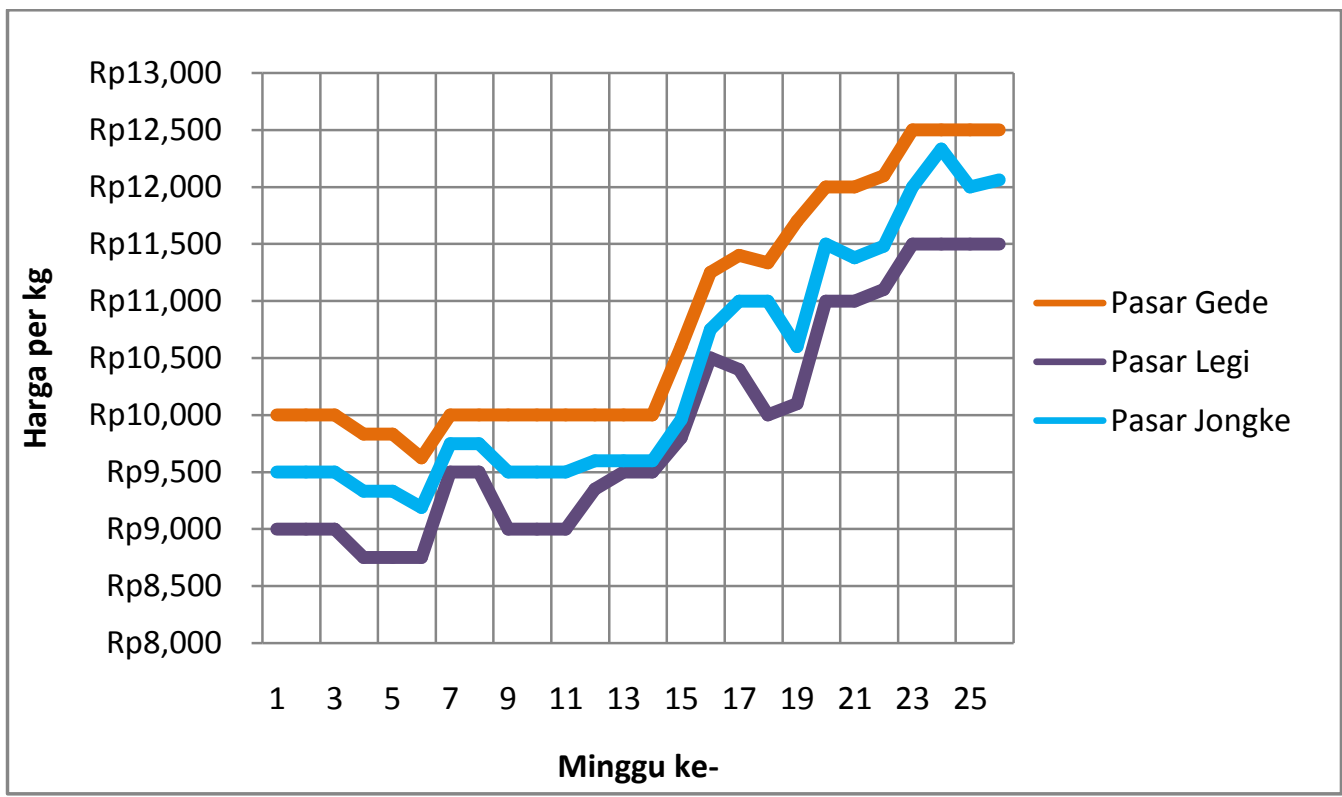

Gambar 3. Harga Minyak Goreng Curah 30 November 2015 - 19 Mei 2016

\section{B. Disparitas Harga}

Gambar4menunjukkangrafik fluktuasi harga minyak goreng yang terjadi di Surakarta.Pasar Gede dan Pasar Jongke mendapat suplai minyak goreng dari pasar induk yaitu Pasar Legi.Harga jual pada Pasar Legi merupakan harga beli pada Pasar Gede dan Pasar Jongke. 


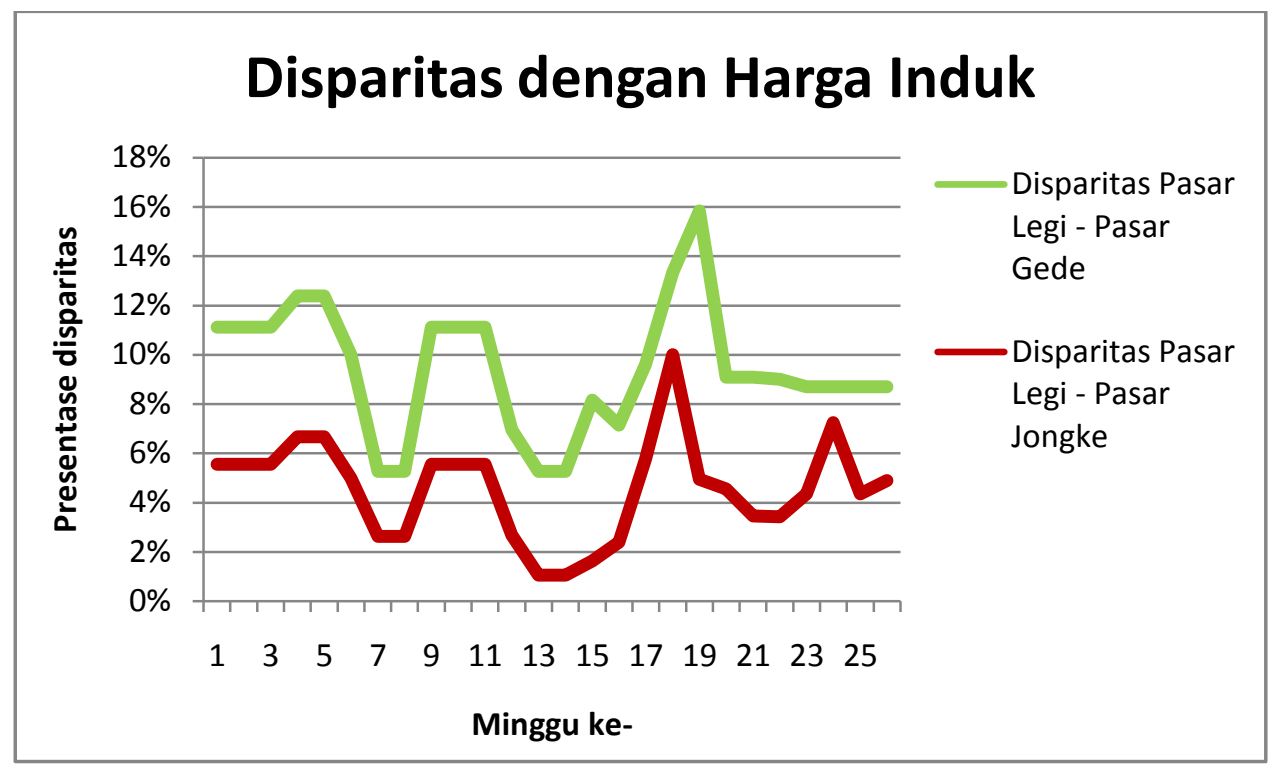

Gambar 4. Harga Minyak Goreng Curah 30 November 2015 - 19 Mei 2016

Gambar 4 menunjukkan disparitas yang terjadi antara Pasar Legi dengan Pasar Gede serta Pasar Legi dengan Pasar Jongke, disparitas harga yang terjadi pada pasar Gede lebih besar daripada yang terjadi pada pasar Jongke. Disparitas yang terjadi pada Pasar Gede berkisar antara 5\% hingga 16\%.Disparitas paling tinggi pada Pasar Gede terjadi pada akhir Maret 2016 (minggu ke-18) sebesar 16\%, dimana harga induk adalah sebesar Rp 10.000 dan harga pada Pasar Gede adalah Rp 11.700, sehingga terjadi disparitas harga sebesar Rp 1.600. Sedangkan disparitas terendah yaitu 5\% terjadi pada minggu ke-6, ke-7, ke-12, dan ke-13 atau pada minggu pertama dan kedua Januari 2016 dan minggu ketiga dan keempat Februari 2016. Kemudian, disparitas yang terjadi pada Pasar Jongke memiliki nilai yang lebih rendah yaitu pada kisaran $1 \%$ hingga $10 \%$. Nilai disparitas tertinggi terjadi pada minggu ketiga bulan Maret 2016 (minggu ke-17), dimana harga induk adalah sebesar Rp10.000 dan harga pada Pasar Jongke adalah Rp 11.000, sehingga terjadi disparitas harga sebesar Rp 1.000. Sedangkan nilai disparitas paling rendah yaitu sebesar $1 \%$ terjadi pada minggu ke-12 dan ke-13 atau pada minggu ketiga dan keempat Februari 2016. Disparitas harga pada tingkat terendah untuk kedua pasar terjadi pada waktu yang sama yaitu minggu ketiga dan keempat Februari 2016.

\section{Penentuan Lokasi Operasi PasarSatu Titik}

Kota Surakarta merupakan kota yang memiliki luas wilayah sebesar 44,04 $\mathrm{km}^{2}$ dengan jumlah penduduk sebanyak 552.650 jiwa. Kota Surakarta memiliki lima kecamatan, yaitu Kecamatan Banjarsari, Jebres, Laweyan, Pasar Kliwon, dan Serengan. Tabel 2 menjelaskan tentang luas wilayah danjumlahpendudukpadamasingmasing kecamatan tersebut. 
Tabel 2. Luas wilayah dan jumlah penduduk tiap kecamatan di Kota Surakarta

\begin{tabular}{llccr}
\hline \multirow{2}{*}{ No } & \multicolumn{2}{c}{ Kecamatan } & Luas Wilayah & \multicolumn{2}{c}{ Jumlah penduduk } \\
& & $(\mathbf{k m 2})$ & n & \% \\
\hline \hline 1 & Banjarsari & 14.81 & 175,379 & $31.73 \%$ \\
2 & Jebres & 12.58 & 142,136 & $25.72 \%$ \\
3 & Laweyan & 8.64 & 97,990 & $17.73 \%$ \\
4 & Pasar Kliwon & 4.82 & 84,010 & $15.20 \%$ \\
5 & Serengan & 3.19 & 53,135 & $9.61 \%$ \\
\hline & Jumlah & 44.04 & 552,650 & $100.00 \%$ \\
\hline
\end{tabular}

Sumber : Data Kependudukan Kota Surakarta Tahun 2014, diolah

Kebutuhan terhadap minyak goreng tiap kecamatan dipengaruhi oleh jumlah penduduk per kecamatan. Jumlah penduduk dipengaruhi oleh angka kelahiran, angka kematian, dan jumlah migrasi netto.Jumlah migrasi netto adalah jumlah migran yang masuk ke suatu provinsi dikurangkan dengan jumlah migran yang keluar dari suatu provinsi. Jumlah penduduk adalah penjumlahan antara jumlah penduduk awal dengan angka kelahiran dan migrasi netto dan kemudian dikurangkan dengan angka kematian.

Berdasarkan data Kantor Ketahanan Pangan Kota Surakarta pada tahun 2015, diketahui bahwa jumlah kebutuhan minyak goreng di Kota Surakarta adalah sebesar 384.979 kg.Kebutuhan tersebut dikalikan dengan persentase jumlah penduduk sehingga didapatkan kebutuhan minyak per kecamatan.Kebutuhan minyak goreng tertinggi adalah di Kecamatan Banjarsari yaitu sebesar $122.747 \mathrm{~kg}$ sedangkan yang terendah adalah di KecamatanSerenganyaitusebesar $36.511 \mathrm{~kg}$.

Tabel 3. Kebutuhan minyak goreng tiap kecamatan di Kota Surakarta

\begin{tabular}{llrrrrrr}
\hline No & Kecamatan & $\begin{array}{c}\text { Angka } \\
\text { Kelahiran }\end{array}$ & $\begin{array}{c}\text { Angka } \\
\text { Kematian }\end{array}$ & $\begin{array}{c}\text { Migrasi } \\
\text { Netto }\end{array}$ & $\begin{array}{c}\text { Jumlah } \\
\text { penduduk }\end{array}$ & Persentase & $\begin{array}{c}\text { Kebutuhan } \\
\text { Minyak }\end{array}$ \\
\hline \hline 1 & Banjarsari & 3,349 & 1,297 & 1,310 & 178,741 & $32 \%$ & 123,132 \\
2 & Jebres & 2,317 & 1,297 & 367 & 143,523 & $26 \%$ & 98,871 \\
3 & Laweyan & 1,722 & 1,297 & 578 & 98,993 & $18 \%$ & 68,195 \\
4 & Pasar Kliwon & 1,535 & 1,297 & 334 & 84,582 & $15 \%$ & 58,267 \\
5 & Serengan & 888 & 1,297 & 279 & 53,005 & $9 \%$ & 36,514 \\
\hline & Jumlah & 9,811 & 6,484 & 2,868 & 558,845 & $100 \%$ & 384,979 \\
\hline
\end{tabular}

Sumber :Profil Perkembangan KependudukanKota Surakarta Tahun 2014, diolah

Kota Surakarta memiliki 19 pasarkomoditas tradisional yang tersebar di lima kecamatan. Untuk melakukan operasi pasar, harus ditentukan lokasi yang tepat terlebih dahulu. Pada penelitian ini, digunakan penentuan lokasi operasi pasar menggunakan metode pusat gravitasi.Pada metode ini, dilakukan penentuan koordinat pada 19 pasar komoditas tersebut dengan menggunakan aplikasi Google Maps.Data kebutuhan per kecamatan di Kota Surakarta yang telah didapatkan kemudian dibagi rata pada setiap pasar di kecamatan tersebut yang dapat dilihat pada Tabel 3.

Nilai koordinat dari lokasi operasi pasar didapatkan dari hasil perhitungan menggunakan rumus (1) dan (2) adalah sebagai berikut.

$$
\begin{aligned}
C_{x} & =\frac{-2.911988}{384,979} \\
& =-7.5640184
\end{aligned}
$$




$$
\begin{aligned}
C_{y} & =\frac{42663.473}{384,979} \\
& =110.820237
\end{aligned}
$$

Berdasarkan perhitungan tersebut, didapatkan koordinat lokasi operasi pasar berada pada titik X, Y yaitu -7.564019, 110.820261.Koordinat tersebut kemudian dimasukkan pada aplikasi Google Maps untuk mengetahui posisi koordinat tersebut pada peta Surakarta. Lokasi tersebut ditunjukkan pada Gambar 4. Dengan tanda merah adalah lokasi 19 pasar komoditas tradisional di Surakarta dan tanda biru adalah lokasi operasi pasar berdasarkan perhitungan yang telah diperhitungkan. Lokasi tersebut terletak pada salah satu rumah penduduk, sehingga lokasi yang dipilih adalah yang berada berdekatan pada koordinat dan cocok untuk digunakan untuk operasi pasar. Lokasi yang dipilih adalah berada pada lapangan di depan Pasar Ngarsopuro, Surakarta dengan koordinat $-7.568210,110.823662$. Lapangan tersebut dipilih karena sangat luasjikadigunakanuntukmelakukanoperasipasar.

\begin{tabular}{|c|c|c|c|c|c|c|c|c|}
\hline No & Kecamatan & Kode & Nama Pasar & Koordinat $(\mathbf{X}, \mathbf{Y})$ & Kebutuhan & $\begin{array}{c}\text { Kebutuhan per } \\
\operatorname{pasar}\left(w_{i}\right)\end{array}$ & $\mathbf{d}_{\mathbf{i x}} \mathbf{w}_{\mathbf{i}}$ & $d_{i y} w_{i}$ \\
\hline 1 & \multirow{5}{*}{ Banjarsari } & $\mathrm{A}$ & Pasar Nongko & $-7.558335,110.814948$ & \multirow{5}{*}{123.132} & 24.626 & $\begin{array}{l}-186134,33 \\
\end{array}$ & 2728969,50 \\
\hline 2 & & $\mathrm{~B}$ & Pasar Ngumbul & $-7.554917,110.810675$ & & 24.626 & $-186050,15$ & 2728864,27 \\
\hline 3 & & $\mathrm{C}$ & Pasar Legi & $-7.562787,110.824523$ & & 24.626 & $-186243,96$ & 2729205,30 \\
\hline 4 & & $\mathrm{D}$ & Pasar Bangunharjo & $-7.558619,110.803489$ & & 24.626 & $-186141,32$ & 2728687,31 \\
\hline 5 & & E & Pasar Ayu Balapan & $-7.557147,110.823019$ & & 24.626 & $-186105,07$ & 2729168,26 \\
\hline 6 & \multirow{6}{*}{ Jebres } & $\mathrm{F}$ & Pasar Tanggul & $-7.571230,110.841695$ & \multirow{6}{*}{98.871} & 16.478 & $-124762,18$ & 1826500,05 \\
\hline 7 & & G & Pasar Nusukan & $-7.546827,110.821499$ & & 16.478 & $-124360,06$ & 1826167,25 \\
\hline 8 & & $\mathrm{H}$ & Pasar Ngemplak & $-7.554323,110.830242$ & & 16.478 & $-124483,58$ & 1826311,32 \\
\hline 9 & & I & Pasar Mojosongo & $-7.553441,110.839553$ & & 16.478 & $-124469,05$ & 1826464,75 \\
\hline 10 & & $\mathrm{~J}$ & Pasar Jebres & $-7.562543,110.839778$ & & 16.478 & $-124619,04$ & 1826468,46 \\
\hline 11 & & $\mathrm{~K}$ & Pasar Gede & $-7.569131,110.832650$ & & 16.478 & $-124727,60$ & 1826351,00 \\
\hline 12 & \multirow{4}{*}{ Laweyan } & $\mathrm{L}$ & Pasar Purwosari & $-7.562903,110.797726$ & \multirow{4}{*}{68.195} & 17.049 & $-128937,60$ & 1888956,21 \\
\hline 13 & & M & Pasar Penumping & $-7.569717,110.807647$ & & 17.049 & $-129053,77$ & 1889125,35 \\
\hline 14 & & $\mathrm{~N}$ & Pasar Kadipolo & $-7.572727,110.813055$ & & 17.049 & $-129105,08$ & 1889217,55 \\
\hline 15 & & $\mathrm{O}$ & Pasar Jongke & $-7.568178,110.790026$ & & 17.049 & $-129027,53$ & 1888824,93 \\
\hline 16 & \multirow{3}{*}{ Pasar Kliwon } & $\mathrm{P}$ & Pasar Sangkrah & $-7.574189,110.834779$ & \multirow{3}{*}{58.267} & 19.422 & $-147109,10$ & 2152679,88 \\
\hline 17 & & Q & Pasar Joglo & $-7.539606,110.821170$ & & 19.422 & $-146437,41$ & 2152415,56 \\
\hline 18 & & $\mathrm{R}$ & Pasar Gading & $-7.583649,110.827017$ & & 19.422 & $-147292,83$ & 2152529,13 \\
\hline 19 & Serengan & $\mathrm{S}$ & Pasar Harjodaksino & $-7.584093,110.820882$ & 36.514 & 36.514 & $\begin{array}{l}-276928,59 \\
\end{array}$ & 4046557,82 \\
\hline \multicolumn{5}{|c|}{ Jumlah } & 384.979 & 384.979 & $-2911988,25$ & 42663463,89 \\
\hline
\end{tabular}

Tabel 4. Koordinat dan kebutuhan minyak goreng tiap pasar komoditas di Kota Surakarta

Sumber : Google Maps, diolah 


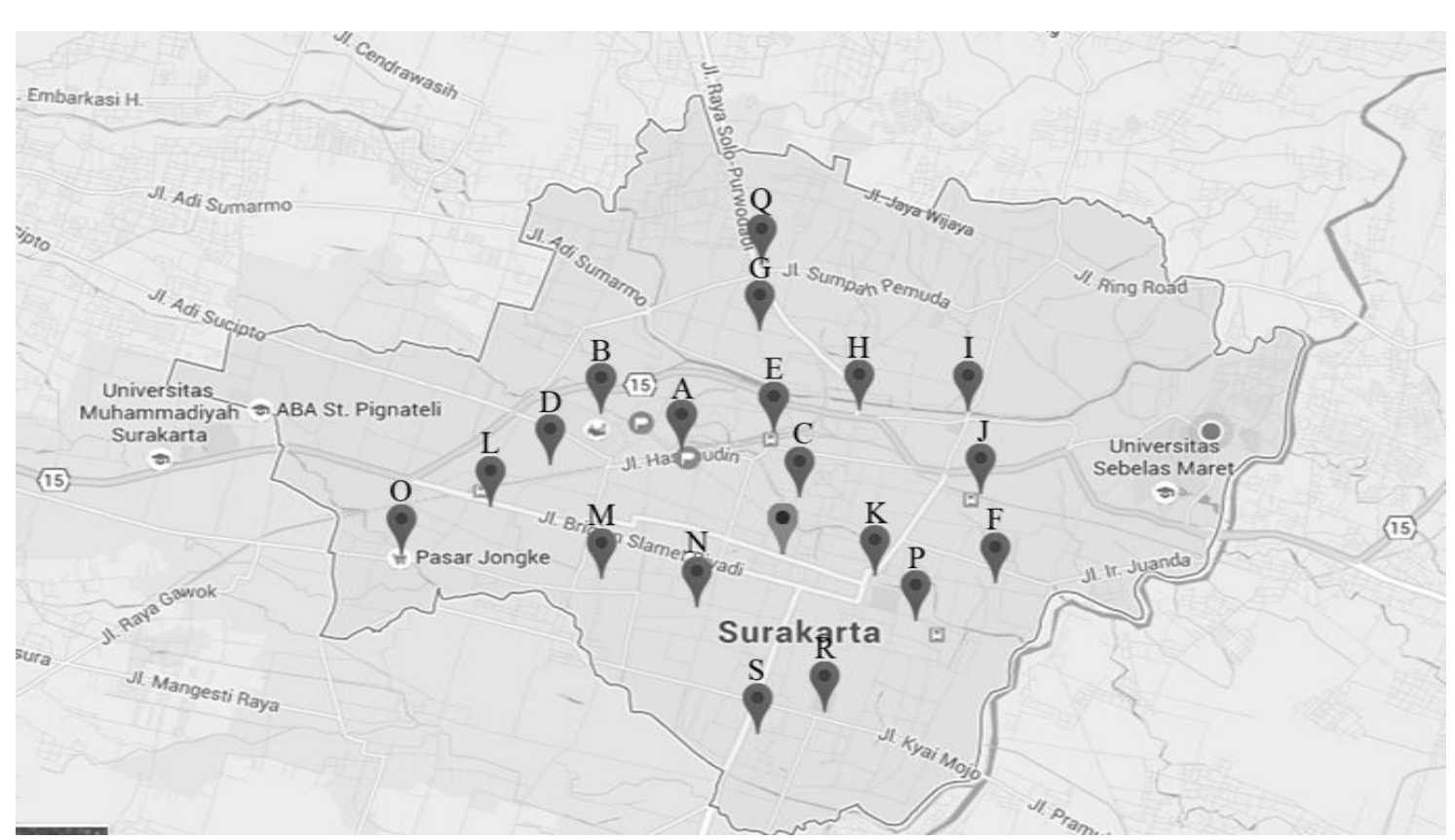

Gambar 5. Lokasi satu titik, 19 pasar komoditas (merah) dan lokasi operasi pasar (biru)

\section{Penentuan Lokasi Operasi Pasar Dua Titik}

Berdasarkan hasil penentuan lokasi pasar yang telah dilakukan dengan satu diperoleh lokasi riil pada lapangan di depan Pasar Ngarsopuro, Surakarta dengan koordinat $-7.568210,110.823662$. kemudian dalam penentuan lokasi operasi pasar dengan dua titik kota surakarta akan dibagi menjadi dua region yaitu region barat dan region timur. Pembagian ini berdasarkan latitude lokasi awal, yaitu lokasi dengan latitude yang lebih kecil daripada -7.568210 masuk pada region barat dan lokasi dengan latitude yang lebih besar daripada -7.568210 masuk pada region timur.

Tabel 5 menunjukkan hasil pembagian dan perhitungan dengan menggunakan metode pusat gravitasi pada region barat.Nilai koordinat dari lokasi operasi pasar region barat didapatkan dari hasil perhitungan menggunakan rumus (1) dan (2) adalah sebagai berikut

$$
\begin{aligned}
C_{x} & =\frac{-1.808 .280,91}{239.116} \\
& =-7.562374 \\
C_{y} & =\frac{26.496 .954,01}{239.116} \\
& =110.812362
\end{aligned}
$$

Berdasarkan perhitungan tersebut, didapatkan koordinat lokasi operasi pasar berada pada titik X, Y yaitu -7.562734, 110.812362. Koordinat tersebut memiliki lokasi yang berdekatan dan cocok digunakan untuk operasi pasar adalah halaman Dinas Perindustrian dan Perdagangan Surakarta. 
Tabel 5. Koordinat dan kebutuhan minyak goreng tiap pasar komoditas di Kota Surakarta Region Barat

\begin{tabular}{|c|c|c|c|c|c|c|c|c|}
\hline No & Kecamatan & Kode & Nama Pasar & Koordinat $(\mathbf{X}, \mathbf{Y})$ & Kebutuhan & $\begin{array}{c}\text { Kebutuhan per } \\
\operatorname{pasar}\left(\mathbf{w}_{\mathrm{i}}\right) \\
\end{array}$ & $\mathbf{d}_{\mathrm{ix}} \mathbf{w}_{\mathrm{i}}$ & $\mathbf{d}_{\mathrm{iy}} \mathbf{w}_{\mathrm{i}}$ \\
\hline 1 & \multirow{4}{*}{ Banjarasari } & A & Pasar Nongko & $-7.558335,110.814948$ & \multirow{4}{*}{98.505} & 24.626 & $-186134,33$ & 2728969,50 \\
\hline 2 & & $\mathrm{~B}$ & Pasar Ngumbul & $-7.554917,110.810675$ & & 24.626 & $-186050,15$ & 2728864,27 \\
\hline 3 & & $\mathrm{D}$ & Pasar Bangunharjo & $-7.558619,110.803489$ & & 24.626 & $-186141,32$ & 2728687,31 \\
\hline 4 & & $\mathrm{E}$ & Pasar Ayu Balapan & $-7.557147,110.823019$ & & 24.626 & $-186105,07$ & 2729168,26 \\
\hline 5 & Jebres & $\mathrm{G}$ & Pasar Nusukan & $-7.546827,110.821499$ & 16.478 & 16.478 & $-124360,06$ & 1826167,25 \\
\hline 6 & \multirow{4}{*}{ Laweyan } & $\mathrm{L}$ & Pasar Purwosari & $-7.562903,110.797726$ & \multirow{4}{*}{68.195} & 17.049 & $-128937,60$ & 1888956,21 \\
\hline 7 & & M & Pasar Penumping & $-7.569717,110.807647$ & & 17.049 & $-129053,77$ & 1889125,35 \\
\hline 8 & & $\mathrm{~N}$ & Pasar Kadipolo & $-7.572727,110.813055$ & & 17.049 & $-129105,08$ & 1889217,55 \\
\hline 9 & & $\mathrm{O}$ & Pasar Jongke & $-7.568178,110.790026$ & & 17.049 & $-129027,53$ & 1888824,93 \\
\hline 10 & Pasar Kliwon & $\mathrm{Q}$ & Pasar Joglo & $-7.539606,110.821170$ & 19.422 & 19.422 & $-146437,41$ & 2152415,56 \\
\hline \multirow[t]{2}{*}{11} & Serengan & $\mathrm{S}$ & Pasar Harjodaksino & $-7.584093,110.820882$ & 36.514 & 36.514 & $-276928,59$ & 4046557,82 \\
\hline & & & Jumlah & & 239.116 & 239.116 & $-1808280,91$ & 26496954,01 \\
\hline
\end{tabular}

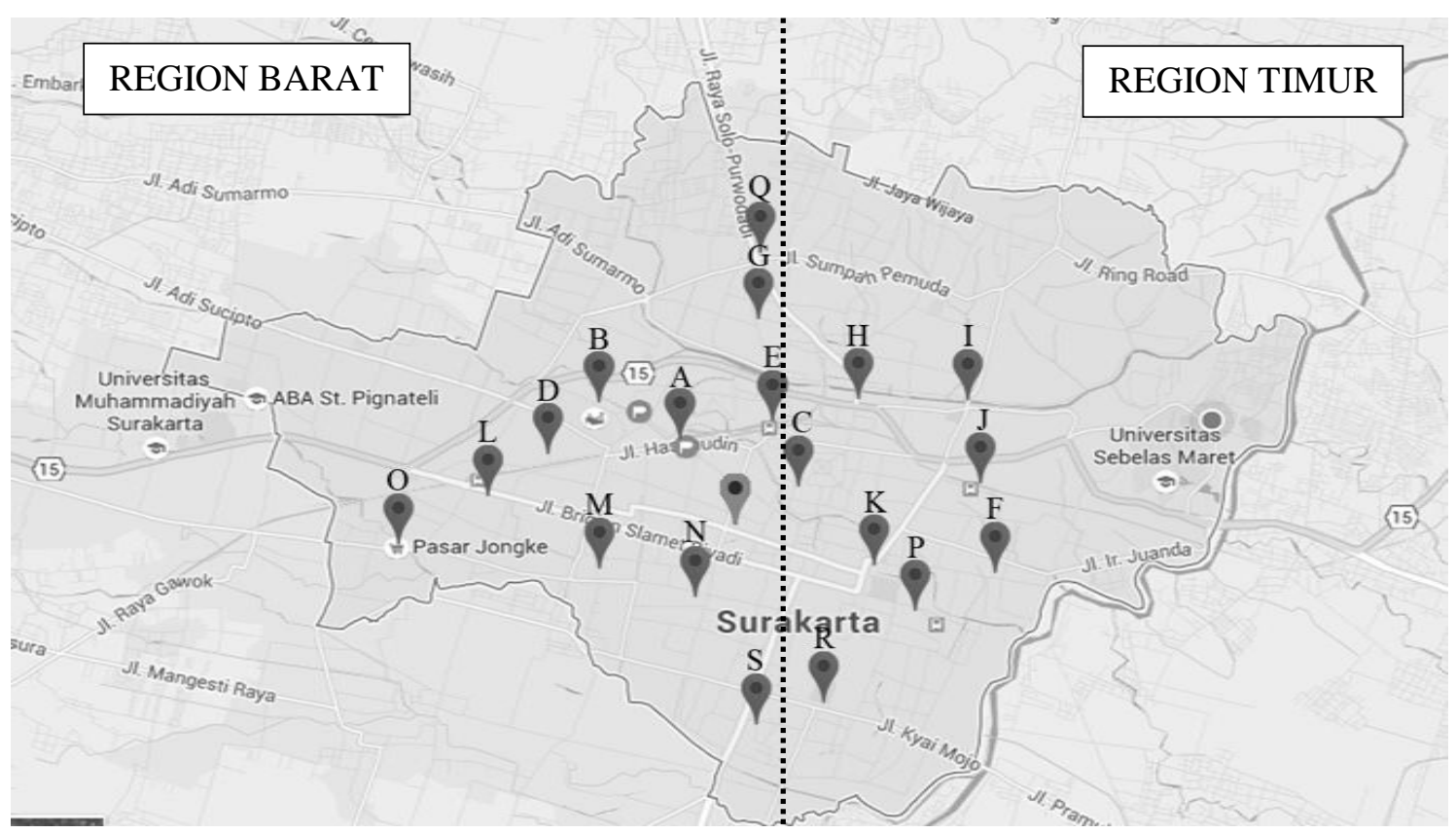

Gambar 6. Lokasi dua titik, 19 pasar komoditas (merah) dan lokasi operasi pasar (biru)

Tabel 6menunjukkanhasil pembagian dan perhitungan dengan menggunakan metode pusat gravitasi pada region timur. Nilai koordinat dari lokasi operasi pasar region barat didapatkan dari hasil perhitungan menggunakan rumus (1) dan (2) adalah sebagai berikut

$$
\begin{aligned}
C_{x} & =\frac{-1.103 .707,34}{145.863} \\
& =-7.566714 \\
C_{y} & =\frac{16.166 .509,88}{145.863} \\
& =110.833146
\end{aligned}
$$

Berdasarkan perhitungan tersebut, didapatkan koordinat lokasi operasi pasar berada pada titik X, Y yaitu -7.566714, 110.833146.Koordinat tersebut kemudian dimasukkan pada aplikasi Google Maps untuk mengetahui posisi koordinat tersebut pada peta Surakarta. Lokasi tersebut terletak pada pinggir jalan raya dan tidak memungkinkan untuk dilakukan operasi pasar, sehingga lokasi lain yang berdekatan untuk digunakan operasi pasar. Lokasi yang dipilih adalah beradap ada halaman depan 
Benteng Vastenburg, dengan koordinat-7.572526, 110.831248. Lokasi tersebut dipilih karena cukup luas untuk diadakannya operasi pasar dan hanya membutuhkanwaktu 3 menitdarilokasiriil.

Tabel 6. Koordinat dan kebutuhan minyak goreng tiap pasar komoditas di Kota Surakarta Region Timur

\begin{tabular}{|c|c|c|c|c|c|c|c|c|}
\hline No & Kecamatan & Kode & Nama Pasar & Koordinat $(\mathbf{X}, \mathbf{Y})$ & Kebutuhan & $\begin{array}{c}\text { Kebutuhan per } \\
\text { pasar }\left(w_{i}\right)\end{array}$ & $d_{i x} w_{i}$ & $d_{i y} w_{i}$ \\
\hline 1 & Banjarasari & $\mathrm{C}$ & Pasar Legi & $-7.562787,110.824523$ & 24.626 & 24.626 & $-186243,96$ & 2729205,30 \\
\hline 2 & \multirow{5}{*}{ Jebres } & $\mathrm{F}$ & Pasar Tanggul & $-7.571230,110.841695$ & \multirow{5}{*}{82.392} & 16.478 & $-124762,18$ & 1826500,05 \\
\hline 3 & & $\mathrm{H}$ & Pasar Ngemplak & $-7.554323,110.830242$ & & 16.478 & $-124483,58$ & 1826311,32 \\
\hline 4 & & $\mathrm{I}$ & Pasar Mojosongo & $-7.553441,110.839553$ & & 16.478 & $-124469,05$ & 1826464,75 \\
\hline 5 & & $\mathrm{~J}$ & Pasar Jebres & $-7.562543,110.839778$ & & 16.478 & $-124619,04$ & 1826468,46 \\
\hline 6 & & $\mathrm{~K}$ & Pasar Gede & $-7.569131,110.832650$ & & 16.478 & $-124727,60$ & 1826351,00 \\
\hline 7 & \multirow{2}{*}{ Pasar Kliwon } & $\mathrm{P}$ & Pasar Sangkrah & $-7.574189,110.834779$ & \multirow{2}{*}{38.845} & 19.422 & $-147109,10$ & 2152679,88 \\
\hline \multirow[t]{2}{*}{8} & & $\mathrm{R}$ & Pasar Gading & $-7.583649,110.827017$ & & 19.422 & $-147292,83$ & 2152529,13 \\
\hline & & & Jumlah & & 145.863 & 145.863 & $-1103707,34$ & 16166509,88 \\
\hline
\end{tabular}

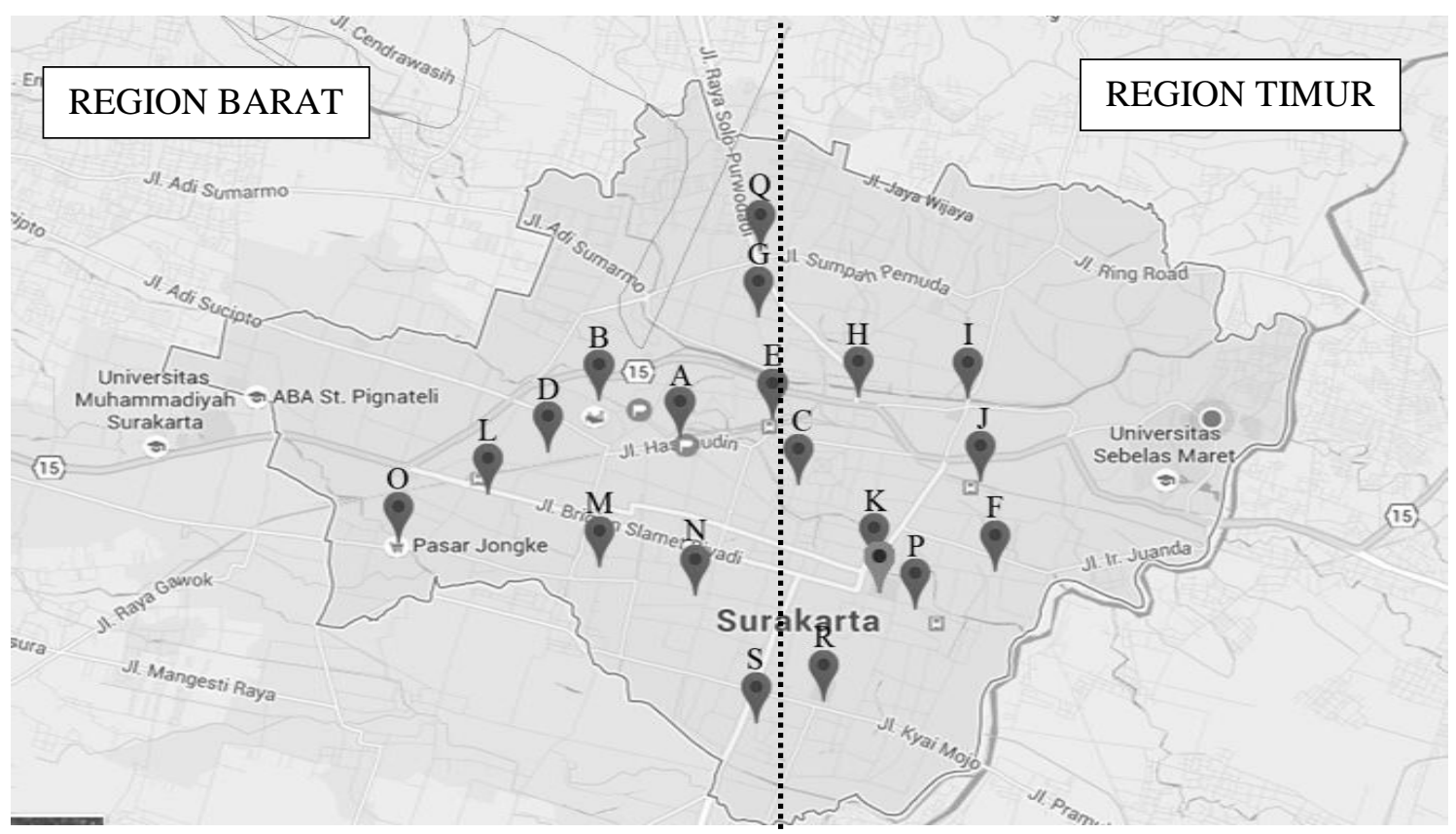

Gambar 7. Lokasi dua titik, 19 pasar komoditas (merah) dan lokasi operasi pasar (biru)

\section{E. Penentuan Kuantitas Minyak Goreng untuk Operasi Pasar}

Penentuan kuantitas minyak goreng untuk operasi pasar dapat dilakukan dengan menggunakan teori keseimbangan pasar. Penentuan in dilakukan agar kuantitas yang disediakan ketika melakukan operasi pasar sesuai dengan yang dibutuhkan masyarakat menggunakan rumus (3) adalah sebagai berikut.

$$
\begin{gathered}
\frac{P-11.500}{12.500-11.500}=\frac{Q-123.132}{98.871-123.132} \\
Q=-24,26 P+402.133,5
\end{gathered}
$$

Harga Rp 11.500 (P1) adalah harga dari Pasar Legi dengan kuantitas (Q1) dari Pasar Legi, dan harga Rp 12.500 (P2) adalah harga dari Pasar Gede dengan kuantitas (Q2) dari Pasar Gede.Untuk operasi pasar, diinginkan harga yang lebih murah dari kedua pasar, maka ditentukan harga sebesar Rp 10.500 per kg, sehingga untuk kuantitasnya adalah sebagai berikut. 


$$
\begin{aligned}
Q & =-24,26(P)+402.133,5 \\
& =-24,26(10.500)+402.133,5 \\
& =147.403,5 \mathrm{~kg} \text { per bulan }
\end{aligned}
$$

Kuantitas operasi pasar yang didapatkan adalah sebesar $147.403,5 \mathrm{~kg}$ per bulan atau sebesar 4.913,45 kg per hari atau sekitar 27 drum minyak goreng curah sehari.

\section{KESIMPULAN DAN SARAN}

Operasi pasar adalah suatu kegiatan yang dilakukan oleh pemerintah atau kerja sama pemerintah dengan lembaga usaha untuk menghindari terjadinya kenaikan harga suatu barang, yang dilakukan dengan cara droping atau injeksi, untuk meningkatkan suplai melalui pedagang swasta, BUMN, atau langsung ke pedagang eceran pada waktu harga meningkat atau dengan operasi pasar murah. Pada penelitian ini, diusulkan kepada Dinas Perindustrian dan Perdagangan Kota Surakarta untuk melakukan operasi pasar di dua titik dengan kuantitas sebanyak 4.913,45 kg ketika harga yang diharapkan adalah sebesar Rp 10.500,00 per kg. Operasi pasar tersebut bertujuan untuk mengurangi lonjakan harga yang biasanya terjadi ketika hari besar tiba.

Implikasi manajerial dari model yang telah disusun dapat digunakan sebagai bahan pertimbangan bagi Dinas Perindustrian dan Perdagangan serta TPID dalam menentukan lokasi dan jumlah minyak goreng yang dibutuhkan untuk operasi pasar. Selain itu manfaat lain dapat dirasakan oleh masyarakat kota Surakarta yang bertindak sebagai konsumen yaitu dapat memperoleh minyak goreng dengan harga yang sesuai.

Operasi pasar hanya dapat digunakan untuk menyelesaikan masalah jangka pendek saja, untuk penyelesaian masalah jangka menengah dapat menggunakan papan informasi yang dipasang pada setiap pasar. Namun untuk kondisi sekarang informasi yang ditampilkan hanya informasi harga, sebaiknya dinas juga menampilkan informasi mengenai stok atau pasokan minyak goreng di setiap pasar. Saran lain yang di berikan adalah ketika melakukan operasi pasar konsumen harus memperlihatkan KTP untuk menghindari broker atau penjual yang membeli barang di operasi pasar dan kemudian dijual kembali ke masyarakat. Penelitian selanjutnya dapat dilakukan dengan menambahkan kapan waktu yang tepat untuk operasi pasar dan menambahkan pertimbangan tingkat kepadatan penduduk pada masing-masing kecamatan di Surakarta.

\section{DAFTAR PUSTAKA}

[1] Badan Perijinan dan Penanaman Modal Daerah Provinsi Kalimantan Timur, 2009, Investasi Industri Minyak Goreng Kelapa Sawit.

[2] Dispendukcapil, 2015, Data Agregat Kependudukan Tahun 2014.

[3] Dispendukcapil, 2015, Profil Perkembangan Kependudukan Kota Surakarta 2014.

[4] Hazliansyah, 2016, Pemkot Surakarta Siapkan Pasar Murah Selama Ramadhan dan Lebaran. http://nasional.republika.co.id/berita/nasional/daerah/16/06/03/ o870nu 280 pemkot- surakarta- siapkan- pasar- murah- selama- ramadhan- dan- lebaran (diakses tanggal 20 Juni 2016).

[5] Heizer, J. dan Render, B, 2013, Operations Management. Global Edition, Pearson, London.

[6] Huifeng, Ji danAigong, Xu, 2008, The Method of Warehouse Location Selection Based on Gis and Remote Sensing Images. Remote Sensing And Spatial Information Sciences. Vol. XXXVII. Part B2. 
[7] Kemendag, 2012, Peraturan Menteri Perdagangan Republik Indonesia Nomor 04/MDAG/PER/1/2012 Tentang Penggunaan Cadangan Beras Pemerintah untuk Stabilisasi Harga.

[8] Nurendah, Y dan Mulyana, M, 2012, Analisis Strategi Lokasi Ritel Dan Citra Toko Giant Botani Square Bogor. Jurnal Ilmiah Kesatuan, Vol.14, No. 1, Hal. 21-32.

[9] Nuyanti, S. 2005. Analisa Keseimbangan Sistem Penawaran dan Permintaan Beras di Indonesia. Jurnal Agro Ekonomi, Vol. 23, No.1, Hal. 71-81.

[10] Onnela, Nona. 2015. Determining The Optimal Distribution Center Location. Thesis of Tampereen Teknillinen Yliopisto.

[11] Pranoto, 2015, Kendalikan Harga, Operasi Pasar Digelar. http://jatengterkini.com/ berita/819/kendalikan-harga-operasi-pasar-digelar(diaksestanggal 20 Juni 2016).

[12] Rahayu, Aji, Husamah, Nugroho, A.D., 2007, Studi Frekuensi Penggorengan dari Minyak Jelantah Bermerek dan Tidak Bermerek Terhadap Nekrosis Sel Hati. PKM Penulisan Ilmiah (PKMI): UniversitasMuhammadiyah Malang.

[13] Saraswati, Trisha Gilang, 2015, Model Gravitasi Sebagai Alat Evaluasi dan Penentuan Lokasi Gudang Pada Bisnis Retail. Business Journal - Jurnal Bisnis dan Sosial, Vol. 1, No. 2.

[14] Selimi, Arta danSvensson, T., 2013, Localization of a Distribution Center for Locally Produced Fruit and Vegetables : A Case Study of SvenskaOdlarlaget and Samodlarna. Thesis of Departement of Management Accounting and Logistics, Linnaeus University.

[15] Wahyuniarti, Dwi, 2013, Tinjauan Pasar Minyak Goreng. Kementerian Perdagangan Republik Indonesia.

[16] Wilson, 2003, Location Modeling in Logistics : A Decision Maker Defined Approach. RMIT University, School of Management

[17] Ying, Zhao X, 2014, Based on Gravity Method of Logistics Distribution Center Location Strategy Research. Management and Computer Science : Atlantis Press.

[18] Yulia, Eva, Mulyati, A.H., Nuraeni, F., 2011, Kualitas Minyak Goreng Curah yang Berada di Pasar Tradisional di Daerah Jabodetabek pada Berbagai Penyimpanan. 